\title{
PRAKTIK BANK THITHIL DAN IMPLIKASINYA MENURUT PANDANGAN MASYARAKAT MUSLIM WILAYAH PERKAMPUNGAN BETHEK KOTA MALANG
}

\author{
Arnanda Aji Saputra, Multifiah, dan Asfi Manzilati \\ Fakultas Ekonomi dan Bisnis Universitas Brawijaya Malang \\ Jalan Veteran Malang 65145 Indonesia \\ E-mail: paranggaruda@gmail.com/ HP. 085649509998
}

\begin{abstract}
The present study aimed at finding out various practices of Bank Thithil at Bethek Urban Village, Malang, along with the people's perception and the impact of such practices towards the people's welfare. Employing qualitative approach, this study focuses on the people's perception, particularly those belonging to debtors trapped in Bank Thithil, such bank's creditors, and some local cultural leaders, who lived at Bethek Urban Village, Malang. Data collection was carried out by interviews, observation and documentation. In analyzing the data, Miles Huberman's analysis was employed which consisted of the following action: collection, reduction, display, and conclusion drawing supported by a phenomenological method which tried to capture and understand the reality. The result showed that Bank Thithil at Bethek Urban Village belonged to an informal financial organization as it was not a legal entity. As a consequence, the creditors may set rules of loan and sanctions without any reference to the legal law of financial organizations in Indonesia. The people's perception towards Bank Thithil was various; some people felt fine with its practices because they need it and some another people strongly disagreed for some reasons, one is the prohibition on Islamic law.
\end{abstract}

Keyword: Bank Thithil, debitur, kreditur, lembaga keuangan informal, kesejahteraan

Penduduk kalangan menengah ke bawah di Indonesia mencapai titik yang cukup tinggi. Menurut Asian Development Bank (ADB), penduduk kalangan menengah ke bawah mengalami peningkatan yang pesat yaitu dari 45 juta jiwa pada tahun 1999 menjadi 93 juta jiwa pada tahun 2006 (Asril, 2012). Fenomena sosial tersebut menjadi titik gerak pembuat kebijakan (pemerintah) untuk berupaya terus membangun Indonesia menjadi negeri yang lebih baik. Salah satu upaya pemerintah dalam mensejahterakan penduduk kalangan menengah ke bawah diwujudkan dengan melakukan kerjasama terhadap lembaga-lembaga donor. Lembaga donor berperan penting sebagai lembaga yang memberikan bantuan baik berupa hibah maupun pinjaman kepada masyarakat. Menurut Venny (2010), pemberian hibah atau pinjaman kepada masyarakat tersebut memiliki fungsi dan peran untuk mendorong berbagai reformasi dalam tata kelola kemasyarakatan di segala bidang. Termasuk di dalamnya reformasi dalam bidang ekonomi dan kesejahteraan.

Dana bantuan dari lembaga-lembaga donor di Indonesia tidak langsung diberikan kepada masyarakat sebagai obyek, tetapi disalurkan melalui lembaga-lembaga swadaya masyarakat 
(LSM) atau Lembaga Keuangan Bukan Bank (LKBB) dan perbankan. Dana untuk peningkatan kesejahteraan yang diberikan oleh lembaga-lembaga donor kepada perbankan dan LKBB cukup besar yakni sekitar Rp 4,6 triliun pada tahun 2002 dan diperkirakan terus meningkat pada tahun-tahun berikutnya (Paguyuban Institute, 2009). Perbankan dan LKBB ini terus bergerak untuk memberikan dana dari lembaga donor kepada masyarakat melalui proyek-proyek yang mereka rancang.

Khususnya dalam meningkatkan peranan usaha masyarakat kecil dan menengah, bank dan LKBB berperan sebagai lembaga yang mampu memberikan akses dana pinjaman berbunga ringan kepada masyarakat serta menjangkau kalangan menengah ke bawah (Ashari, 2006). Akan tetapi pada kenyataannya bank kurang dapat diakses masyarakat secara mudah daripada LKBB. Sebab transaksi yang terlampau kecil tetapi dalam jumlah unit usaha yang sangat besar ini menyebabkan transaction cost sangat tinggi (Susila, 2007). Sehingga LKBB menjadi sebuah lembaga andalan untuk memberikan dana bantuan kepada masyarakat menengah kebawah. Secara formalitas hukum, LKBB terbagi menjadi LKBB Informal dan Formal. LKBB Informal memiliki gerak fleksibel karena tidak berbadan hukum, sedangkan LKBB Formal umumnya tetap memperlakukan usaha kecil sama dengan usaha menengah ke atas dalam pengajuan pembiayaan, di antaranya mencakup kecukupan jaminan, modal, maupun kelayakan usaha (persyaratan 5-C) yang dipandang memberatkan pelaku pengusaha kecil.

Bukan saja sektor usaha mikro dan kecil yang membutuhkan dana pinjaman, sektor rumah tangga juga seringkali membutuhkan pinjaman untuk memenuhi kebutuhan hidupnya. Khususnya rumah tangga miskin yang kebutuhan sehari-hari mereka masih belum dapat dipenuhi secara baik, sedangkan LKBB Formal dan perbankan menerapkan syarat yang tidak mudah dipenuhi oleh mereka. Oleh sebab itu, baik pelaku usaha mikro maupun rumah tangga miskin berupaya untuk mencari alternatif dana pinjaman guna memenuhi kebutuhan mereka.

Salah satu alternatif yang dilakukan oleh mereka adalah mencari dana talangan melalui LKBB Informal baik melalui tengkulak maupun rentenir atau dalam bahasa masyarakat (Jawa) lebih dikenal dengan sebutan Bank Thithil. Sebagaimana Krishnamukti (2003; dalam Susila, 2007) menyatakan bahwa tanpa akses yang baik kepada LKBB Formal, mayoritas rumah tangga miskin akan bergantung kepada pembiayaannya sendiri yang sangat terbatas atau pada Lembaga Keuangan Informal, seperti Bank Thithil di Jawa, tengkulak ataupun pelepas uang secara umum (rentenir).

Secara ekonomi, Bank Thithil sangat merugikan masyarakat ditinjau dari sistem serta bunga yang dipatok kreditur terhadap debiturnya. Apabila ditinjau dari sisi Islam pun terdapat 
unsur riba yang dapat mengurangi kesejahteraan masyarakat terlebih masyarakat kalangan menengah ke bawah yang memiliki rasio perbandingan pendapatan dan pengeluaran yang jauh.

Praktik Bank Thithil tidak hanya merambah pedesaan di Jawa, akan tetapi di kota-kota besar pun praktik ini terus berkembang. Apabila menilik Kota Malang, praktik Bank Thithil tetap eksis dilakukan di beberapa wilayah. Sebagaimana penelitian yang dilakukan Permana (2010) di wilayah perkampungan Kecamatan Sukun Kota Malang. Menurutnya Bank Thithil di wilayah ini cukup agresif yang dipicu oleh sulitnya kondisi masyarakat untuk mendapatkan akses pinjaman dari bank dan LKBB Formal dengan persyaratan yang mudah. Selain itu tingkat kemiskinan penduduk setempat merupakan salah satu faktor pemicu eksisnya Bank Thithil di wilayah tersebut.

Bila meninjau Kecamatan Klojen Kota Malang, yang merupakan pusat kota juga tidak terlepas dari praktik dan pergerakan Bank Thithil. Kecamatan ini memiliki banyak fasilitas memadai dalam sektor keuangan, seperti bank, koperasi ataupun LKBB Formal lain yang menyediakan fasilitas dana talangan berbunga ringan. Akan tetapi walaupun banyak fasilitas yang ada, angka kemiskinan masih mencapai angka 3.432 kepala keluarga (Pemerintah Kota Malang, 2009). Dari 3.432 kepala keluarga, mayoritas penduduk miskin di Kecamatan Klojen mayoritas berkumpul pada satu perkampungan yaitu perkampungan Bethek. Perkampungan ini terletak persis di sebelah Timur pusat perekonomian Kota Malang di Jalan Soekarno-Hatta. Sehingga tampak fenomena yang berseberangan terjadi di Kecamatan Klojen Kota Malang, di satu sisi merupakan pusat bisnis dan perekonomian Kota Malang dan di sisi lain mayoritas penduduk kalangan menengah ke bawah berkumpul di dekat pusat bisnis tersebut. Sebagai langkah untuk melihat makna di balik fenomena yang telah dipaparkan maka tulisan ini membedah tentang praktik dan gerak Bank Thithil di wilayah perkampungan Bethek Kota Malang.

Berdasarkan latar belakang di atas, penelitian ini bertujuan sebagai berikut: (1) Mengetahui bentuk praktik Bank Thithil di wilayah perkampungan Bethek Kota Malang; (2) mengetahui persepsi masyarakat mengenai keberadaan Bank Thithil dan implikasinya terhadap kesejahteraan masyarakat di wilayah perkampungan Bethek Kota Malang.

\section{METODE}


Dengan mengacu kepada tujuan yang ingin dicapai maka penelitian ini dapat digolongkan ke dalam penelitian deskriptif kualitatif. Metode ini dirasa tepat untuk dipilih karena memerlukan kajian yang mendalam terhadap fenomena yang terjadi serta dapat mengungkap makna di balik kejadian yang ada.

Metode kualitatif adalah metode penelitian yang berusaha memahami dan menafsirkan makna suatu peristiwa interaksi tingkah laku manusia dalam situasi tertentu menurut prespektif peneliti. Usman (2009) menyatakan bahwa metode kualitatif lebih berdasarkan pada filsafat fenomenologis yang mengutamakan penghayatan. Pernyataan Usman ini diperkuat dengan pernyataan Oetomo (2006) bahwa keunggulan metode kualitatif ialah memiliki strategi penyelidikan yang naturalistis dan induktif dalam mendekati suatu suasana tanpa hipotesishipotesis yang telah ditentukan sebelumnya.

Penelitian ini menekankan kepada data primer. Sehingga untuk mendapatkan data yang diperlukan dalam penelitian, ada unsur penting yang harus dipenuhi, yaitu informan yang berperan sebagai salah satu obyek dalam pengambilan data. Dalam penelitian ini informan dibagi manjadi dua unsur pokok, yaitu informan kunci dan informan pendukung. Informan kunci merupakan informan yang memiliki peranan penting dalam mengungkap data primer yang sangat diperlukan dalam penelitian. Informan kunci dalam penelitian ini adalah warga yang terjerat langsung kepada Bank Thithil di perkampungan Bethek Kota Malang, beserta pelaku Bank Thithil yang juga merupakan salah satu warga setempat. Sedangkan informan pendukung adalah, informan yang memiliki peran penting untuk mendukung pernyataan informan kunci serta menimbang apakah kisah informan kunci dapat diterima kebenaran dan tanggung jawabnya ataukah tidak.

Ditinjau dari pendekatannya, penelitian ini menggunakan pendekatan Fenomenologi. Metode kasus ini dipergunakan untuk mendapatkan informasi yang mendalam tentang obyek yang diteliti. Menurut Hendarso (2006) pendekatan Fenomenologi merupakan pendekatan yang memahami sudut pandang perilaku obyek penelitian. Agar penelitian dapat terarah, maka penelitian ini didasarkan atas teori yang mendukungnya. Pendekatan teori yang dipakai adalah khasanah Islam, teori tentang LKBB Formal dan Informal serta teori analisis multiparadigma. Untuk menunjang kevalidan hasil penelitian, digunakan sumber data secara primer yaitu data yang diperoleh langsung dari suatu kejadian atau informasi yang didapatkan dari informan.

Peneliti melakukan analisis data dengan menggunakan model interaktif dan pendekatan teori. Model Interaktif terdiri atas tiga komponen analisis yaitu, reduksi data, sajian data, dan penarikan kesimpulan (Milles \& Huberman, 1992 dalam Sujadi, 2005). Reduksi data dapat 
diartikan sebagai proses pemilihan, pemusatan perhatian pada penyederhanaan, pengabstrakan dan transformasi data kasar yang muncul dari catatan penulis di lapangan. Penyajian data merupakan alur penting dalam membatasi suatu "penyajian" sebagai kumpulan informasi yang disusun untuk memberi kemungkinan adanya penarikan kesimpulan atau pengambilan tindakan. Penarikan kesimpulan/verivikasi, yaitu suatu pernyataan ringkas yang dihimpun berdasarkan file notes yang tertuang dalam sebuah paparan penelitian. Dengan demikian penelitian ini mengikuti pola pemikiran kualitatif yang bersifat empirical inductive .

\section{PEMBAHASAN}

\section{Peran Intermediasi Lembaga Keuangan}

Lembaga donor berperan penting sebagai lembaga yang memberikan bantuan kepada masyarakat baik berupa hibah maupun pinjaman kepada mereka. Menurut Venny (2010), pemberian hibah atau pinjaman kepada masyarakat tersebut memiliki fungsi dan peran untuk mendorong berbagai reformasi dalam tata kelola kemasyarakatan di segala bidang. Termasuk di dalamnya reformasi dalam bidang ekonomi dan kesejahteraan. Secara khusus lembaga donor juga memiliki peranan dalam memberikan bantuan teknis untuk meningkatkan knowledge, attitude, and skill (KAS) kepada forum multipihak maupun Masyarakat, serta melakukan monev terhadap program, proyek atau kegiatan yang didanai atau disponsori oleh lembaga donor yang bersangkutan (Lembaga Penelitian SMERU, 2004).

Terkait dengan penanggulangan kemiskinan, Lembaga Penelitian SMERU (2004) menyatakan perlunya aspek kelembagaan yang dibentuk secara khusus untuk menangani hal tersebut. Sebagaimana telah dilakukan oleh beberapa daerah dengan dibentuknya sebuah Komite Penanggulangan Kemiskinan, sebab lembaga donor juga memiliki peran dan fungsi sebagai salah satu stake holders penting dalam menanggulangi kemiskinan, sehingga perlu untuk dijalin suatu komunikasi dan koordinasi yang mendalam. Hal tersebut dimaksudkan sebagai penentu kebijakan tentang besaran dana yang dianggarkan guna merealisasikan program penanggulangan kemiskinan yang telah dirancang.

Sebagai langkah praktis untuk menyalurkan dana kepada masyarakat secara langsung, lembaga donor menggunakan jasa Lembaga Keuangan Bukan Bank (LKBB) sebab lembaga ini mampu menangani menyalurkan dana saecara langsung kepada masyarakat (Venny, 2010). Sebagai langkah keamanan maka biasanya lembaga donor bekerja sama dengan LKBB yang memiliki badan hukum tetap sehingga LKBB ini bersifat formal. 
Mayoritas dana yang disalurkan oleh LKBB Formal kepada masyarakat dalam bentuk pinjaman ataupun bantuan usaha kepada sektor tertentu sesuai dengan program yang dicanangkan bersama pemerintah daerah. Sebagaimana data dari Kemanterian KUMK tahun 2006, menyebutkan bahwa tahun 2005 terdapat lebih dari 26 juta unit usaha mikro dan kecil yang bergerak di sektor pertanian, peternakan, kehutanan dan perikanan (Susila, 2007). Sedangkan secara teknis Bank meminjamkan dana kepada pelaku usaha dengan syarat ketat dan jumlah nominal minimum yang ditentukan guna meminimalisir risiko. Keterbatasan usaha kecil dan mikro dalam mengakses lembaga perbankan formal ini merupakan potensi pasar yang bisa menjadi ladang garapan lembaga keuangan.

Selama itu LKBB Formal merupakan lembaga yang disinyalir mampu untuk memenuhi modal UMKM karena LKBB Formal mampu menyesuaikan pelayanan dengan karakter UMKM yang cenderung dianggap tidak bankable oleh sektor perbankan komersial (Lawang, 2007). Dalam implementasinya LKBB Formal juga dianggap lebih efisien dari perbankan karena kedekatannya kepada masyarakat yang dilayani sehingga dapat mengurangi biaya-biaya transaksi yang biasa terjadi pada perbankan. Oleh sebab itu, mayoritas lembaga donor bekerja sama dengan pemerintah lebih memilih 'menitipkan' danannya kepada LKBB guna disalurkan kepada masyarakat pelaku usaha mikro yang membutuhkan.

\section{Lembaga Keuangan Bukan Bank (LKBB) Formal}

LKBB Formal merupakan lembaga keuangan yang memiliki badan hukum dan telah terdaftar sebagai LKBB Formal melalui akta notaris (Imelia, 1998). Akan tetapi Lembaga ini tidak diatur secara langsung oleh undang-undang perbankan nasional serta tidak terikat erat dengan peraturan perbankan yang ada (Idris, 2006). Selain itu LKBB Formal biasanya hanya mengakses sektor produksi rakyat berskala besar (Majidi, 1991; dalam Imelia, 1998).

Fungsi LKBB Formal yaitu melayani kebutuhan ekonomi masyarakat yang tidak bisa di jangkau oleh lembaga perbankan, maka pemerintah berupaya untuk melakukan peningkatan ekonomi masyarakat dengan menstimulus investasi dari masyarakat serta membantu mereka dalam mendapatkan dana kredit bunga ringan sesuai dengan kebutuhan mereka melalui LKBB tersebut (Arthesa, 2006). Di Indonesia status LKBB Formal dan geraknya di bawah kontrol serta pengawasan Kementerian Keuangan RI c.q Direktorat Jenderal Lembaga Keuangan (Rindjin, 2000) sehingga pemerintah turut andil dalam melakukan pengawasan dan kontrol terhadap jalannya LKBB Formal. Dengan turut andilnya pemerintah maka bunga pinjaman disesuaikan 
dengan kebijakan pemerintah daerah sesuai dengan kemampuan masyarakat setempat (Simorangkir, 2004).

LKBB Formal memiliki karakteristik berupa rumitnya prosedur administrasi, mementingkan aspek legalitas, biaya administrasi tinggi serta bunga rendah (Aryeetey, 1996; dalam Imelia 1998). Prosedur administrasi yang cukup ketat dari LKBB Formal untuk mencegah seminimal mungkin tingkat kredit macet yang akan terjadi (Simorangkir, 2004). Selain itu administrasi berperan penting untuk mempertahankan legalitas yang berfungsi sebagai prosedur keamanan terhadap aset LKBB Formal serta menjaga hak-hak nasabah dan menjaga kekuatan hukum terhadap LKBB Formal tersebut (Kasmir, 2004). Beberapa jenis LKBB Formal cukup dikenal di Indonesia adalah Asuransi, Dana Pensiun, Pegadaian, serta Koperasi Simpan Pinjam. LKBB Formal tersebut disinyalir mampu memberikan kredit secara langsung ke masyarakat dalam skala kecil dan memiliki syarat lebih fleksibel.

Susilowati (2007, dalam Irfan, 2010) berpendapat bahwa apabila ditinjau dari distribusi keuangan secara konvensional sistem distribusi saat ini lebih didominasi oleh dua mazhab utama yaitu ortodok dan strukturalis. Kedua sistem distribusi tersebut telah mengalami kegagalan dalam menekan laju kemiskinan dan kesenjangan pendapatan secara efektif. Menanggapi hal ini Ashari (2006) mengungkapkan bahwa kredit bunga ringan masih yang dilakukan LKBB Formal masih kurang efektif untuk menekan laju kemiskinan, sebab terdapat unsur kelembagaan yang kurang fleksibel serta terdapat bunga yang menjadi sebuah beban bagi masyarakat apabila mengalami kerugian. Akibatnya masyarakat memilih alternatif lain sebagai wujud untuk mendapatkan biaya usaha kecil atau hidup mereka, baik pembiayaan sendiri maupun melalui lembaga ilegal.

\section{Lembaga Keuangan Bukan Bank (LKBB) Informal dan Bank Thithil}

LKBB Informal merupakan suatu lembaga keuangan yang tidak berbadan hukum (Imelia, 1998) sehingga pergerakannya bebas tanpa ada intervensi dari aparat pemerintah dan hanya mampu mengakses usaha kecil dan mikro yang masih sederhana (Basri, 1985). Selain itu LKBB Informal memiliki karakteristik administrasi dan persyaratan yang sederhana, mementingkan saling percaya, biaya administrasi rendah akan tetapi suku bunga tinggi sehingga kreditur pun bebas menentukan suku bunga tanpa takut dengan aparat atau lembaga keuangan yang lainnya (Majidi, 1991; dalam Imelia, 1998).

LKBB Informal memiliki ciri khas umum yaitu prosedur serta perjanjian peminjaman cepat, berdasarkan perjanjian lisan atau tertulis yang sederhana serta berlandaskan atas 
kepercayaan daripada legalitas dan terkadang tanpa jaminan (Wibowo \& Munawar, 2002). Oleh karena lembaga informal bergerak tidak berlandaskan peraturan hukum dan juga tidak memiliki kekuatan hukum tetap, maka seringkali ia disebut sebagai LKBB Ilegal (Mudiono, 2005).

Kemudahan administrasi dan dana yang cepat cair merupakan suatu alasan yang sering dijadikan masyarakat untuk memilih LKBB Informal daripada LKBB Formal. Hal ini sesuai dengan pernyataan (Hidayat, 2009) bahwa nasabah LKBB informal biasanya meminjam untuk berbagai tujuan seperti konsumsi atau modal usaha kecil. Hal ini ditangkap oleh LKBB Informal dan direalisasikan dalam bentuk kecepatan serta fleksibilitas administratif. Sementara, hubungan LKBB Formal dengan nasabah cenderung mendasarkan pada kontrak-kontrak yang berbasiskan pada kelengkapan infomasi. Oleh sebab itulah banyak masyarakat di beberapa wilayah masih eksis dalam menggunakan jasa LBB Informal walaupun seringkali bunga yang ditetapkan irrasional.

LKBB Informal yang sering dikenal oleh masyarakat di Jawa (Jawa Timur dan Tengah) adalah Bank Thithil. Bank Thithil mampu memberikan pinjaman yang jumlahnya lebih kecil daripada bank konvensional serta cepat administrasi dan pencairan dananya (Kartono, 2004). Sistem Bank Thithili hampir sama seperti rentenir, akan tetapi memiliki perbedaan secara khusus yang ditampakkan pada sistem kalkulasi bunga dan cara pengembaliannya.

Dijelaskan oleh Kartono (2004) bahwa Bank Thithil yaitu orang atau organisasi ilegal yang mempunyai aktivitas meminjamkan uang (atau juga dalam bentuk barang) kepada orang lain yang memerlukannya dengan imbalan bunga dan cara pengembalian yang telah ditetapkan oleh 'kreditur'. Hubungan antara kreditur Bank Thithil dengan debitur mayoritas cukup dekat, karena proses pembayaran cicilan pinjaman dipungut sendiri oleh kreditur dan dilakukan setiap waktu secara kontinyu.

Mayoritas Bank Thithil di Jawa tidak menarik agunan/jaminan hutang kepada peminjam, sebab uang yang dipinjamkan terlampau kecil (Ashari, 2006; Kartono, 2004). Oleh karena LKBB Informal tidak berbadan hukum, maka pemasaran organisasi ilegal tersebut bertumpu kepada jaringan dan kepercayaan sosial, begitupula dengan Bank Thihtil. Selain itu, hukum tidak dapat ditegakkan secara sempurna pada Bank Thithil (Yekti, 2009). Sehingga sanksi debitur yang melanggar komitmen hanya dapat dilakukan melalui keterlibatan sosial yang mendalam sebagai mekanisme sanksi sosial. Seperti sindiran, gunjingan yang beritanya akan menyebar luas. Sanksi-sanksi tersebut merupakan bentuk kontrol sekaligus sanksi sosial terhadap pelanggar komitmen terhadap pelaku Bank Thihtil. 


\section{Persepsi Praktik Bank Thithil Menurut Ekonomi Konvensional}

Dalam praktiknya, Bank Thithil menarik bunga tinggi dan tata cara pengembalian yang ditetapkan oleh kreditur tanpa didasarkan oleh undang-undang secara resmi. Praktik ini dipandang sebagai praktik yang memiliki polemik fiqih tersendiri di dalam khasanah Islam, terutama dalam masalah hukum tentang rate (bunga pinjaman). Devinisi rate secara terminologis umum adalah suatu tambahan harga yang ditetapkan untuk pinjaman finansial, seringkali dinyatakan dalam bentuk persentase dan dihitung dari jumlah uang yang dipinjam (Wirdyaningsih, 2005: 21).

Dalam Ilmu Ekonomi, kebijakan moneter dapat dianalisis dengan kerangka IS-LM atau keseimbangan di pasar barang dan pasar uang. Keduanya saling terkait satu sama lain, karena dalam transaksi pembelian barang membutuhkan uang, dan tidak ada uang bila tidak ada barang. Satria (2009) menyatakan bahwa pembentukan kurva permintaan agregat secara umum dibentuk oleh keseimbangan pasar uang dan barang, dimana titik keseimbangan keduanya akan bertemu pada tingkat suku bunga tertentu. Hal ini menandakan bahwa suku bunga berperan penting dalam membentuk suatu harga. Pergeseran keseimbangan pasar uang dan pasar barang menyebabkan suku bunga juga turut bergeser dan pergeseran suku bunga ini dapat berdampak meluas bagi perekonomian dalam dan luar negeri tergantung dari seberapa besar ketergantungan antara wilayah satu dengan yang lainnya.

Dalam sejarah masa lalu, uang hanya berfungsi sebagai alat tukar dan penentu nilai suatu barang dan tidak lebih dari itu. Pada jaman Nabi Muhammad terdapat mata uang dinar yang dicetak oleh Bangsa Romawi dan Dirham yang dicetak oleh Bangsa Persia, akan tetapi fungsi mata uang itu secara umum digunakan untuk menentukan nilai suatu barang dan sebagai alat tukar. Sedangkan masa kini, uang tidak hanya sebatas itu tetapi telah mengalami perkembangan dalam fungsinya. Uang telah menjadi sebuah komoditi untuk mencari keuntungan dengan cara memperjualbelikannya serta memanfaatkannya sebagai ladang bisnis dan investasi (Satria, 2009). Masih menurut Satria bahwa permintaan uang ditentukan oleh tiga motif (Satria, 2009: 20), yaitu: (1) Kebutuhan uang untuk transaksi; (2) sarana berjaga-jaga; dan (3) sarana spekulasi. Motiv ketiga inilah yang saat ini banyak dilakukan oleh mayoritas pebisnis bidang moneter baik perbankan maupun lembaga keuangan lainnya. Motif spekulasi telah memberikan banyak kontribusi dalam membuat kebijakan dan membentuk pola hidup sosialmasyarakat. Salah satu yang tampak saat ini adalah kebijakan suku bunga pinjaman dan gairah hutang oleh masyarakat, baik yang memiliki motif keterpaksaan atau bisnis. 


\section{Persepsi Praktik Bank Thithil Menurut Khasanah Islam}

Pandangan konvensional telah jelas bahwa bunga merupakan unsur penting yang tidak dapat dipisahkan dari pergerakan pasar dan ekonomi secara umum. Akan tetapi rate (bunga pinjaman) dalam Islam memiliki pandangan yang lain (Wirdyaningsih, 2005). Karena dalam Islam suatu muamalah tetap terkait dengan aqidah (keyakinan) yang terkandung di dalamnya. Selain itu Islam menekankan kemaslahatan dan pandangan yang menyeluruh terhadap suatu sistem muamalah baik yang bernafaskan ekonomi klasik maupun ekonomi modern.

Para pakar ekonomi Islam memiliki beberapa pendapat tentang rate yang kini menjadi unsur penting dalam sebuah pergerakan perekonomian. Pendapat pertama adalah 'tidak diperbolehkan', pendapat ini didasarkan secara efektif kepada kategori ar-riba. Ar-riba sendiri secara makna berarti tambahan atau pertumbuhan (Shalah \& Abdullah, 2008). Sedangkan menurut istilah, Shalah \& Abdullah (2008) menyatakan bahwa Ar-riba adalah tambahan khusus terhadap pinjaman yang dimiliki oleh salah satu dari dua pihak yang terlibat hutang piutang. Dalam Islam, Ar-Riba telah banyak dinyatakan dalam Al-Qur'an dan Hadits. Beberapa dalil dalam Al-Qur'an tertuang pada Firman Allah pada Surat Al-Baqarah: 275; Al-Baqarah: Ali Imran: 130; An-Nisa: 161; Ar-Rum: 39 serta ayat-ayat yang lainnya.

Menurut Wirdyaningsih (2005) lain yang membolehkan bunga pinjaman memiliki alasan: (1) Dalam keadaan-keadaan darurat semua yang haram dapat menjadi halal dengan persyaratannya. Berdasarkan Al-Qur'an Surat Al-Maa'idah: 3 (artinya), “...Maka barang siapa terpaksa karena kelaparan tanpa sengaja berbuat dosa, sesungguhnya Allah Maha Pengampun lagi Maha Penyayang." Maka bunga pun diqiyaskan kepada ketidakmampuan umat sebagaimana Allah menerangkan di dalam FirmanNya; (2) hanya bunga yang berlipat ganda saja yang dilarang, adapun suku bunga yang 'wajar' dan 'tidak mendzalimi' diperkenankan. Hal ini merupakan tafsir yang ditafsirkan oleh sebagian orang dengan merujuk kepada AlQur'an Surat Ali-Imrah: 130; (3) keuangan bank serta LKBB sebagai “lembaga hukum” tidak termasuk dalam wilayah hukum taklif, pernyataan ini merupakan pandangan secara liberal dalam Islam; (4) hanya kredit yang bersifat konsumtif saja yang bunganya dilarang, adapun yang produktif tidak demikian, pendapat ini disampaikan oleh kalangan pendukung the productivity theory of interest; (5) Bunga diberikan sebagai ganti rugi (opportunity cost) atas hilangnya "kesempatan" untuk memperoleh keuntungan dari pengelolaan dana tersebut, pendapat ini disampaikan oleh The classical Theory of Interest; dan (6) Bunga diberikan untuk mengimbangi laju inflasi yang mengakibatkan susutnya nilai uang atau daya beli uang itu, 
pendapatan ini dinyatakan oleh pendukung ekonomi realitas. Walaupun para pakar Islam dari beberapa kalangan membolehkan bunga pinjaman, akan tetapi semua bernafaskan upaya untuk mencari jalan kaluar dari suatu keadaan yang terpaksa. Sehingga bunga pinjaman bukanlah sesuatu yang dibolehkan secara mutlak dalam pandangan Islam.

\section{Praktik Bank Thithil di Perkampungan Bethek Kota Malang}

Eksisnya Bank Thithil yang diteliti oleh Permana (2010) dapat berkembang menjadi sebuah monopilstik dalam bisnis keuangan di suatu lokasi tatkala situasi mendukung. Sehingga masyarakat cenderung memilih dengan pertimbangan irrasional daripada pertimbangan secara logis dan theologis. Praktik Bank Thithilpun berbeda-beda di suatu wilayah dengan wilayah yang lainnya, perbedaan itu dipengaruhi oleh interaksi sosial dan budaya setempat (Hari, 2009).

Bila meninjau masyarakat di perkampungan Bethek Kota Malang, mayoritas dari mereka adalah para pengusaha kecil yang terdesak oleh bisnis besar yang berkembang pesat di sekitar wilayah perkampungan tersebut. Begitupula dalam hal lahan, mereka merasa sulit menemukan lahan untuk berdagang dan usaha lainnya karena tanah-tanah kosong yang dahulu disewa oleh group pedagang secara bergotong royong kini diambil alih oleh individu yang memiliki kekuatan modal. Sehingga lahan yang dahulu terhampar luas, saat ini banyak didirikan bangunan-bangunan tinggi. Sebagaimana dinyatakan oleh Pak Shofi'i, salah satu warga sekalius pedagang kecil menuturkan, "Sakniki teng daerah mriki niku njih uuangel wong dodol yo ngepul, njih a? yang sadeyan niku ngepul-pul mboten saged enak. Sakniki pun teng mriki, Soekarno-Hatta ngaler niku kados ngoten, uuangele eram."(Sekarang di daerah situ sulit sekali, orang berjualan ya berebut, ya kan? Yang berjualan itu saling berebut tidak bisa nyaman. Sekarang saja di sini, (di Jalan) Soekarno-Hatta ke Utara itu seperti itu, sulit sekali).

Di sisi lain Akses warga wilayah perkampungan Bethek terhadap LKBB Formal tergolong sulit, begitu pula dengan akses bantuan pemerintah. Pak Soemadi, selaku ketua RT menyatakan bahwa ada beberapa bantuan pemerintah seperti PNPM Mandiri serta P2KP. Bantuan tersebut pada awalnya untuk pelaku usaha produktif saja, akan tetapi terdapat beberapa kendala sehingga penyaluran dana bantuan tidak semuanya tepat sasaran. bantuan berupa P2KP dan PNPM Mandiri juga terbatas untuk pelaku usaha mikro dan kecil saja, sedangkan warga yang berprofesi seperti buruh, sopir dan karyawan lainnya tidak mendapatkan bantuan lainnya. Sebagaimana dituturkan oleh Pak Soemadi, ““...sing angsal P2KP sing usaha thok...sing gadhah usaha (...yang mendapatkan yang memiliki usaha (produktif) saja...yang memiliki usaha).". Hal 
ini memunculkan kecemburuan sosial terhadap beberapa warga yang memang membutuhkan dana akan tetapi bukanlah pelaku usaha mikro dan kecil.

Beberapa kondisi di atas mencerminkan bagaimana warga apabila terdesak dalam memenuhi kebutuhan hidupnya rela melakukan apa saja hingga melakukan hal yang irrasional. Potensi tersebut merupakan sebuah kesempatan emas bagi warga setempat di perkampungan Bethek untuk meraup keuntungan. Warga yang memiliki kekuatan modal dengan dalih menolong tetangganya, memanfaatkan kesempatan ini sebagai peluang guna menjalankan bisnis keuangan ilegal. yang sering dikenal oleh masyarakat yaitu praktik Bank Thithil. Pergeseran pandangan hedonisme pada mayoritas kalangan masyarakat baik atas, menengah maupun bawah telah membentuk sebuah aktivtas ekonomi secara liar. Sehingga pandangan prinsip ekonomi klasik dipandang sebagai sesuatu yang wajar untuk dijalankan guna mendapatkan kuntungan maksimal. Prinsip ekonomi, “Dengan modal yang minimum akan menghasilkan keuntungan maksimum" merupakan hal yang kini menjadi trend di kalangan kreditur Bank Thithil.

\section{Inovasi ‘Unik' yang Dilakukan Kreditur Bank Thithil di Perkampungan Bethek Kota Malang}

Pada umumnya LKBB Informal seperti rentenir meminjamkan nasabahnya dalam bentuk uang, akan tetapi status ilegal mendorong kreditur melakukan inovasi dalam menjalankan usaha keuangannya. Kreditur Bank Thihtil menyadari bahwa kebutuhan masyarakat bukan sekedar uang saja. Akan tetapi kebutuhan pokok berupa makanan dan penunjangnya (sembako) juga merupakan hal yang dibutuhkan masyarakat dalam waktu yang relatif cepat. Peluang ini dimanfaatkan oleh kreditur Bank Thithil di wilayah perkampungan Bethek Kota Malang untuk melakukan inovasi dengan memberikan pinjaman berupa sembilan bahan pokok yang sering dibeli oleh warga sekitar dengan membuka toko kelontong. Kreditur Bank Thithil tersebut melayani kebutuhan warga baik secara cash maupun kredit.

Pelayanan pembelian secara cash sudah biasa diterapkan dalam perdagangan. Akan tetapi apabila aktivitas ini dilakukan oleh usaha keuangan ilegal maka hal ini merupakan sebuah terobosan tersendiri. Sistem pinjaman berupa barang (sembako) dihitung berdasarkan harga yang dibeli oleh pelanggannya. Sehingga apabila pelanggan membeli kebutuhan (semisal beras) dan tidak memiliki uang yang cukup saat itu, maka harga dari kebutuhan yang belum dibayar tersebut masuk dalam hutang yang harus dibayarkan beserta bunga yang telah ditetapkan.

Kreditur Bank Thihtil melakukan praktik di wilayahnya, yaitu dengan menghimpun modal dari hasil hutang kepada Bank. "Niku pun kathah ragade, utang teng BRI (Itu sudah banyak 
kebutuhannya, hutang ke BRI)," kata Bu T yang merupakan salah satu kreditur di perkampungan Bethek Kota Malang. Kreditur meminjam uang dari bank kemudian diputar dengan cara dipinjamkan kepada para nasabah yang membutuhkan. Sisanya digunakan berdagang toko kelontong, dimana selain dijual secara jual beli juga dipinjamkan dengan sistem pinjaman pembelian sembako sebagaimana telah dijelaskan.

Sistem 'rolasan' merupakan sistem unik yang dilakukan Bank Thithil untuk menentukan bunga pinjaman dari nasabahnya. Sistem Rolasan adalah sistem sederhana yang mudah untuk difahami masyarakat awam dalam menghitung bunga kembalian daripada menggunakan nominal persen (\%). Mengingat debitur Bank Thihtil mayoritas masyarakat awam yang membutuhkan perhitungan praktis untuk mengkalkulasi jumlah pinjaman yang harus dikembalikan.

Menurut Hamka \& Danarti (2010), Sistem Rolasan adalah sistem pembayaran yang apabila meminjam '10' akan menjadi '12'. Sedangkan pengalaman yang ditulis Army (2012) sistem Rolasan dapat menyebabkan pokok hutang bertambah dua kali lipat tatkala pada pembayaran pertama, modal tidak dapat dilunasi oleh nasabah. Oleh sebab itu Sistem Rolasan ini umum dilakukan oleh Bank Thihtil baik yang bergerak di pasaran maupun yang bergerak di wilayah perkampungan.

Begitupula kreditur Bank Thithil yang melakukan praktik di wilayah perkampungan Bethek Kota Malang, sistem rolasan yaitu sistem nominal '10' menjad '12' menjadi sebuah sistem yang umum dilakukan oleh Bank Thithil sehingga masyarakat setempat mudah dalam menghitung berapa jumlah pinjaman yang harus dikembalikan. Pak Shofi'i, Salah seorang warga perkampungan Bethek Kota Malang menuturkan, “Teng mriki lek pinjam ngoten niku Mas njih, teng renternir niku sing kulo sanjang. Niku mawon kangelan...Sakniki, teng mriki sakniki gadhah aturan kadosss seratus ribu menjadi seratus dua puluh. Dados bunganipun 20 ribu tiap bulan. Ngarani lek tiang Jowo rolasan, njih a?. (Di sini kalau pinjam seperti itu Mas ya, di rentenir yang saya bilang itu. Itu saja (saya) kesulitan...Sekarang, di sini itu memiliki aturan seperti seratus ribu menjadi seratus dua puluh (ribu). Jadi bunganya 20 ribu tiap bulan. Kalau orang Jawa menyebutnya (sistem) dua belasan, iya kan?"

Sehingga sistem rolasan ditetapkan secara sederhana berdasarkan nominalnya. Apabila nasabah tidak dapat membayar, maka sistem ini akan terus berlipat ganda. Dengan bunga 20 ribu tiap bulan dihitung berdasarkan nominal $\mathrm{Rp}$ 100.000,00 maka nominal '10' akan digandakan menjadi nominal '12' sehingga menjadi Rp 120.000,00. 


\section{Prinsip Penetapan Nasabah oleh Kreditur Bank Thithil}

Ciri khas LKBB Informal adalah lebih mengutamakan kepercayaan terhadap para nasabah daripada sistem administrasi yang rumit (Wibowo \& Munawar, 2002). Begitupula Bank Thithil, kemudahan pencairan dana tanpa administrasi yang rumit merupakan sebuah keunggulan tersendiri. Di sisi lain, status Bank Thithil yang tidak berbadan hukum formal memiliki kelemahan dalam mengontrol gerak keuangannya. Oleh sebab itu Bank Thithil tentu cara sendiri untuk menjaga agar tetap eksis.

Salah satu cara untuk menjaga agar praktik Bank Thithil tetap eksis di suatu wilayah adalah dengan cara menyeleksi nasabah. Sebab nasabah merupakan unsur penting dalam mempertahankan aliran modal kreditur Bank Thithil dan juga mempertahankan eksistensinya di tengah-tengah masyarakat. Oleh sebab itu Bank Thithil memiliki penilaian terhadap nasabah serta keseriusan para nasabah dalam meminjam uang.

Praktik Bank Thithil di wilayah perkampungan Bethek Kota Malang memiliki cara yang mudah untuk menetapkan seorang nasabah layak meminjam uang ataukah tidak. Faktor kedekatan sosial dan kekuatan interaksinya menyebabkan kreditur sangat mengenal karakteristik orang yang akan meminjam yangnya. Sebagaimana Pak Shofi'i, salah satu nasabah menuturkan, "Ya yak apa maneh Mas, sing nyilihi tangga sing disilihi tangga ngoten loh.(Ya bagaimana lagi Mas, yang meminjamkan tetangga dan yang dipinjami tetangga begitu loh)." Dengan kondisi demikian kreditur Bank Thithil yang bergerak di wilayah perkampungan Bethek Kota Malang akan lebih mudah dalam mengorek informasi terhadap para calon debiturnya khususnya tentang kepribadian serta perkembangan ekonomi mereka.

Kepribadian calon peminjam merupakan unsur yang sangat penting untuk menganalisa kelayakan calon debitur Bank Thithil. Faktor ini merupakan faktor penentu apakah seseorang itu berpotensi menimbulkan kredit macet ataukah tidak. Dituturkan oleh $\mathrm{Bu} \mathrm{T}$, selaku kreditur Bank Thithil di wilayah perkampungan Bethek Kota Malang, “Lek kula niki anuuu lek ngoten niku njiiih ngapunten njih, sakniki niku niki pun nate mulakaken kula pun nate kenek. Mula njih sakniki mboten percaya, mula lek kate ngutang teng Pak RT, ngoten. Soale nek kula niku sakniki lek kalih tiyang, njih ngapunten njih Mas kula niku mboten percaya. (Kalau saya ini anu, kalau seperti itu (maksudnya meminjam uang) yaa mohon maaf ya, sekarang itu (sudah tidak seperti dulu), ini sudah pernah yang seperti ini (maksudnya orang asing meminjam uang) maka saya sudah pengalaman dan pernah (ditipu). Maka ya sekarang saya tidak percaya, maka kalau mau meminjam (laporan) ke Pak RT, begitu. Soalnya kalau saya itu sekarang kalau sama orang, ya maaf ya Mas saya itu tidak (mudah) percaya)." 


\section{Cara Pelunasan Pinjaman Oleh Nasabah}

Berbeda antar kreditur Bank Thithil yang satu dengan yang lainnya dalam menarik pinjaman kepada nasabahnya. Mayoritas Bank Thithil menariknya secara angsuran sebagaimana dinyatakan Permana (2010), Kartono (2004) dan juga Damsar (1997). Akan tetapi ada juga yang dikembalikan secara kontan baik pokok pinjaman dan bunga atau pokok pinjaman terlebih dahulu kemudian bunganya dapat diangsur. Sebagaimana keterangan yang dinyatakan oleh Supriatna (2009).

Cara melipatgandakan uang ini juga berbeda antara Bank Thithil yang satu dengan yang lainnya. Mengingat tingkat fleksibilitas praktik Bank Thithil yang tinggi, maka kreditur Bank Thithil pun berhak menentukan tingkat pengembalian pinjaman beserta kelipatannya. $\mathrm{Bu} \mathrm{T}$, kreditur Bank Thithil di wilayah penelitian menetapkan kelipatgandaan pada pinjaman pokok setiap tiga bulan sekali. Sehingga 'misal' nasabah meminjam Rp 100.000,00 maka dengan sistem rolasan dia akan mengembalikan Rp 112.000,00, sedangkan yang terjadi di wilayah perkampungan Bethek harus mengembalikan Rp 120.000,00 berdasarkan pernyataan Pak Shofi'I, "Jadi kapan seratuse, seratus dua puluh kembalinya (Jadi bila meminjam seratus ribu, harus mengembalkan seratus dua puluh ribu)." Sehingga bila menggunakan sistem rolasan yang dilakukan di wilayah perkampungan Bethek bunganya Rp 20.000,00.

Pelipatgandaan pada pokok pinjaman baru akan dimulai pada bulan ketiga. Sebagaimana dinyatakan oleh Pak Shofi'i, “Berarti kapan, sampean mboten saged nganaki tigang ulan mawon njiiih, mpun dadi seratus senam puluh. (Berarti apabila, kamu tidak dapat membayar bunganya tiga bulan saja, sudah menjadi seratus enam puluh ribu)." Sehingga pada bulan kedua pembayaran bunga memang masih Rp 20.000,00, akan tetapi Bu T tetap mengkalkulasikan bunga dengan melipatgandakan menjadi dua puluh ribu lagi. Kemudian pada bulan ketiga, Bu T akan melakukan tagihan sejumlah Rp 60.000,00 dengan kalkulasi yaitu pokok pinjaman ditambahkan dengan tiga kali bunga awal. Tiga kali bunga awal adalah tiga bulan yang belum dibayarkan.

Sedangkan apabila jatuh bulan keempat dan kelima belum dapat membayar secara kontan juga, maka hitungan bunga masih berkisar Rp 60.000,00. Namun apabila bulan keenam tidak bisa membayarnya secara kontan, maka bunga kembali berlipat menjadi Rp 120.000,00. Sehingga apabila dijumlah dengan pokok pinjaman menjadi Rp 220.000,00. Maka boleh jadi, apabila nasabah tidak dapat membayarkan bunga secara kontan beban hutang akan semakin tinggi, hingga pokok pinjaman plus bunga berkembang berlipat-lipat hingga jumlah yang sangat besar. 
Jeratan hutang ke Bu T baru akan berhenti tatkala pokok pinjaman dan bunga dilunasi secara kontan. Akan tetapi, penyelesaian pinjaman hutang kepada Bu T juga dapat diselesaikan dengan melunasi pokok pinjamannya saja dengan melalui proses lobying yang cukup sulit. Pak Shofi'I menurutkan, “Adek kula niki riyin Mas, anake wes berkembang uakeh. Dadose pun kerjo ketekuk ringkel mung iso makani anak bojone ae sek kangelan. Akhire, Alhamdulillah, kapan nika onok Rumah Zakat sing njenengan kalih Mas Arga anu niku. Duko yoknopo, utange pun ditutup...Njih pokoke thok niku sing dibayar, dadose pun entheng pun mboten nganu malih. (Adik saya ini dahulu Mas, 'anaknya' sudah berkembang sangat banyak. Jadi, kerja keras hanya bisa memberi makan anak dan istrinya saja, itu saja masih kesulitan. Akhirnya, Alhamdulillah, kapan itu ada (bantuan dari) Rumah Zakat yang kamu dan Mas Arga anu (upayakan) itu. Saya tidak tahu bagaimana, hutangnya sudah ditutup...Ya, pokok pinjamannya saja yang dibayar, sehingga sudah ringan lah tidak nganu (menagih-nagih) lagi)."

\section{Sanksi Bagi Nasabah; Dominasi Sanksi Moral}

Bank Thithil memberikan sanksi berdasarkan efektifitas untuk diterapkan guna membuat efek jera bagi pelaku (nasabah) kredit macet. Pemberian sanksi tersebut pada intinya juga tidak menekankan pada satu cara, melainkan beragam cara dengan upaya agar tujuan untuk membuat efek jera bagi pelaku kredit macet tersebut berhasil dengan cara di luar hukum, mengingat Bank Thithil tidaklah berbadan hukum.

Sebagaimana dinyatakan oleh Permana (2010) dan keterangan yang ditulis dalam draft kronologis kejadian perkara dari salah seorang narapidana Lapas Wanita Kelas II A (2012) bahwa kreditur Bank Thithil akan melakukan sanksi terhadap nasabahnya yang dirasa menyulitkan proses kembalinya modal pinjaman dengan beberapa cara, mulai dari sanksi psikologis dengan hinaan hingga sanksi moral, yaitu dipermalukan dengan cara menjadikannya bahan pembicaraan di depan para tetangganya.

Begitupula sanksi yang dilakukan Bu T, selaku kreditur Bank Thithil di wilayah perkampungan Bethek Kota Malang terhadap nasabah yang mengalami kredit macet dilakukan dengan beberapa ragam cara. Mulai dari sindiran yang dilakukan di lingkup pertemuan semiformal, seperti PKK, sampai tindakan yang mengarah kepada fisik. Sindiran yang dilakukan Bu T di pertemuan warga yang bersifat semi formal, disampaikan oleh Mbak Yuli, “Oooh, yah mesti ae lah. Soale kannn apa ya Mas ya, kasare kan ben dhina ngomongi kampung. Dadi ngono lah wonge. Lagian nang PKK iku kan ya sering orang ngobrol-ngobrol gitu. Ya kesempatan juga kan. (Oh, ya mesti saja lah. Soalnya kan apa ya Mas, secara kasar kan setiap hari itu membicarakan kampun. Jadi 
seperti itu lah orangnya. Lagi pula di PKK itu kan juga sering orang-orang saling mengobrol seperti itu. Ya kesempatan juga kan.)" Hal senada diungkapkan oleh Bu Minayah, “Yo wongwong iku biasane ngertine tekok PKK...(Iya, orang-orang itu biasanya tahunya dari PKK)."

\section{Dikotomi Pandangan Masyarakat pada Praktik 'Bank Thithil'}

Menurut Hari (2009) Bank Thithil bagi masyarakat memiliki keunggulan dan juga kerugian. Oleh sebab itu masyarakat pun juga berbeda-beda dalam menanggapi praktik Bank Thithil. Begitupula warga di wilayah perkampungan Bethek Kota Malang, mereka memiliki tanggapan tersendiri terhadap praktik Bank Thithil yang beroperasi di wilayahnya.

Di mata masyarakat Bank Thithil tidak sepenuhnya merugikan bagi mereka, kehadirannya justru dinanti-nanti oleh sebagian masyarakat. Bunga yang besar serta sanksi moral yang cukup menekan psikologis nasabah, tidak mereka hiraukan. Warga hanya ingin agar kebutuhan yang menurut mereka mendesak bisa segera terpenuhi walau itu dengan jalan hutang terlebih dahulu. Ketergantungan warga di wilayah perkampungan Bethek terhadap praktik Bank Thithil terbentuk karena salah satu alasan yaitu akses pinjaman untuk memenuhi kebutuhan yang mendesak serta modal usaha di wilayah penelitian cukup sulit. Sebagaimana dituturkan oleh Pak Suryono selaku produsen dan penjual kerupuk berskala rumah tangga di perkampungan wilayah Bethek Kota Malang, "Lek teng mriki butuh dana usaha ngoten. Njih repot njih, sulit. (Kalau di sini membutuhkan dana usaha seperti itu. Ya repot ya, sulit)" Lebih lanjut dijelaskan oleh Mbak Desi, seorang pedagang frozen food siap makan untuk anak-anak, "Iyo, lek nang Koperasi iku biasane kate nyilih ae dideloki opo iso mbayar opo ora. Terus ditakoni jaminane opo. (Iya, kalau di Koperasi itu biasanya akan meminjam saja dilihat apa bisa membayar ataukah tidak. Terus ditanya jaminanya (yang sanggup disetorkan) apa)."

Sedangkan apabila dilihat dari sisi bantuan dari pemerintah, ternyata tidak semua warga di wilayah penelitian mendapatkan bantuan tersebut. Padahal banyak masyarakat yang mengharapkan untuk mendapatkan dana bantuan tersebut, akan tetapi syarat serta jumlah bantuan tersebut seringkali membuat masyarakat menuai kekecewaan. Dituturkan oleh Pak Soemadi selaku Ketua RT 07, "Mboten enten Mas, njih niku loh repote sing anu dugi anu niku disukani ngoten sing gadhah usaha niku. PNPM mandiri niku, sing diparingi sing gadhah usaha thok, nopo macet ngoten. Rumiyin lak macet, nopo mati ngoten P2KP niku macet niku. (Tidak ada Mas, ya itu loh repotnya yang dari situ (maksudnya PNPM Mandiri) yang diberi hanya yang memiliki usaha (produktif) saja. Dahulu kan macet, atau mati begitu, P2KP (juga) macet itu." Oleh sebab itulah Bank Thithil masih menjadi andalan warga setempat. 
Akan tetapi mayoritas warga yang beragama Islam, tidak sepenuhnya menyetujui praktik yang menjamur di wilayah perkampungan Bethek Kota Malang. Al-Qur'an dan Al-Hadits yang mengandung nilai keotentikan secara mutlak, melarang pemeluk agama Islam melarang adanya unsur yang mengarah kepada riba. Sebagaimana dijelaskan di beberapa Surat dalam Al-Qur'an dan nash Hadits Sahih dari Nab Muhammad Shalallahu 'alaihi wa sallam. Sebagaimana dalam AlQur'an juga dijelaskan dalam Q.S Ali-Imran: 130, “Hai orang-orang yang beriman, janganlah kamu memakan riba dengan berlipat ganda dan bertakwalah kamu kepada Allah supaya kamu mendapat keberuntungan."

Pemahaman masyarakat tentang haramnya riba dalam Al-Qur'an dan Hadits bersumber dari berbagai macam informasi. Baik mereka mendapatkan dari pendidikan formal seperti di madrasah maupun pondok pesantren, ataupun dari informasi yang tidak formal seperti dari 'katanya' Pak Kyai, Ustad, atau orang yang memahami tentang permasalahan riba. (Abdurrahman, 2010). Begitupula masyarakat perkampungan Bethek Kota Malang, sebagian tidak setuju dang enggan meminjam pada Bank Thithil dengan alasan keharamannya dalam syariat Islam. Sehingga mereka rela meminjam tetangga dengan pengembalian sesuai pinjaman (Qardh) atau meminjam pada lembaga formal syariah.

Penilaian warga perkampungan Bethek Kota Malang tentang haramnya hasil pinjaman Bank Thithil, dinyatakan oleh Bu Minayah selaku istri takmir mushola setempat, "Jare, wongwong, 'Kok arek-arek kate nyilih duwik nang konooo, kok nganggo duwik haram. (Katanya orang-orang, 'Kok anak-anak mau pinjam uang di sana, kok menggunakan uang haram?)" Alasan status haram dijelaskan lebih lanjut olehnya, "Looh, lah lek nggawe wong tambah sara lak yo gak oleh taaah. Kan nang agama yo wes koyok ngono. (Loh, la kalau membuat orang bertambah susah kan tidak boleh. Dalam agama kan ya sudah seperti itu)."

Dikhotomi pemahaman atas praktik Bank Thithil yang didasarkan atas teologi Islam di wilayah penelitian hingga kini masih merupakan sebuah fenomena yang belum dapat dihindarkan. Maka perlu sosialisasi terhadap masyarakat secara kontinyu dengan langkahlangkah strategis guna menjelaskan apa yang 'benar' di dalam syariat agama Islam. Mengingat mayoritas warga perkampungan Bethek Kota Malang beragama Islam. Maka sosialisasi ini sesuai dengan pengamalan dari Undang-undang Dasar 1945 pasal

\section{KESIMPULAN DAN SARAN}

Kesimpulan 
Praktik Bank Thithil di wilayah perkampungan Bethek Kota Malang dilatarbelakangi oleh kondisi perekonomian warga setempat yang membutuhkan biaya kebutuhan hidup sehari-hari serta biaya untuk mengembangkan usaha mereka yang rata-rata berskala rumah tangga. Di sisi lain mereka kesulitan untuk mengakses bank/LKBB Formal guna mendapatkan pinjaman baik untuk memenuhi kebutuhan pribadi maupun untuk modal usaha mereka. Kondisi tersebut merupakan sebuah peluang besar bagi kreditur Bank Thithil untuk memberikan pinjaman kepada warga yang membutuhkan dengan bunga yang tinggi dan berlipat ganda. Praktik Bank Thithil tidak lepas dari pengamatan dan penilaian warga masyarakat serta memiliki beberapa dampak yang dirasakan oleh warga di wilayah perkampungan Bethek Kota Malang. Terdapat perbedaan pandangan warga masyarakat perkampungan Bethek Kota Malang dalam menanggapi praktik Bank Thithil yang beroperasi di wilayahnya. sebagian warga yang setuju terhadap praktik Bank Thithil karena mereka membutuhkannya, maka mereka masih sering berinteraksi dengan kreditur dan meminjam uang darinya. Adapula warga yang tidak setuju dengan praktik Bank Thithil dan mereka antipati terhadap praktiknya karena beberapa alasan, di antaranya: praktik Bank Thithil yang justru memberatkan masyarakat; status dana pinjaman dari Bank Thithil adalah haram menurut agama serta; perilaku kreditur Bank Thithil yang sering meresahkan warga masyarakat setempat. Warga yang tidak setuju kesemuanya didasarkan atas pandangan Agama Islam yang tidak membolehkan adanya kedzaliman termasuk di dalamnya unsur riba dalam transaksi hutang-piutangnya.

\section{Saran}

Berdasarkan tanggapan masyarakat serta beberapa fenomena yang berimplikasi pada masyarakat Bethek Kota Malang maka dapat diusulkan suatu saran kepada beberapa elemen masyarakat, LSM dan pemerintah guna bersatu untuk menemukan solusi dalam mensejahterakan masyarakat urban khususnya golongan menengah ke bawah. Kemudahan akses lembaga keuangan formal yang sesuai syariah Islam sangatlah penting untuk memfasilitasi kebutuhan masyarakat terhadap lembaga keuangan dan akses mereka untuk meminjam uang secara Islami. Hendaknya lembaga keuangan tersebut juga fleksibel dalam menerapkan aplikasinya, agar bisa juga diakses oleh warga nonmuslim yang membutuhkan. Hal ini sesuai pula dengan prinsip Islam yang rahmatalil 'alamin serta universalitas dalam fungsi dan manfaat syariatnya. 


\section{DAFTAR RUJUKAN}

Al-Qur'an Al-Karim.

Abdurrahman. 2010. Ekonomi Al-Ghazali, Menelusuri Konsep Ekonomi Islam Dalam Ihya' Ulum AlDin. Surabaya: Bina Ilmu.

Army, L. 2012. Lintah Darat Menyerbu Desa, http:/ /laelyarmy.blogspot.com/2012/04/lintahdarat-menyerbu-desa.html. Nove,ber 2012.

Arthesa, A. 2006. Bank dan Lembaga Keuangan Bukan Bank. Jakarta: Indeks.

Ashari. 2006. Potensi Lembaga Keuangan Mikro (LKM) dalam Pembangunan Ekonomi Pedesaan dan Kebijakan. Pusat Analisis Sosial Ekonomi dan Kebijakan Pertanian, TP

Asril, S. Z. 2012. Soal Middle Class (Income) Trap. Padang: Padang Ekspres.

Basri, H. 1985. Masyarakat Nelayan dan Kemiskinan. Ujung Pandang: Unhas.

Damsar. 1997. Sosiologi Ekonomi. Jakarta: Rajawali Press.

Hamka, A.A. \& Danarti, T. Eksistensi Bank Thithil Dalam Kegiatan Pasar Tradisional (Studi Kasus Di Pasar Kota Batu). Journal of Indonesian Applied Economics, 4 (1), 67.

Hari, J.F. 2009. Dampak Pinjaman Kredit Rentenir Terhadap Kesejahteraan Pedagang Pasar Tradisional dalam Tinjauan Ekonomi Islam, Skripsi, Fakultas Syariah Institut Agama Islam Negeri (IAIN) Imam Bonjol Padang.

Hendarso. 2006. Metodologi Penelitian Sosial. Jakarta: Kencana.

Hidayat, A. D. 2009. Peran Lembaga Keuangan dalam Pengembangan Usaha Budidaya Air Tawar di Kabupaten Banjar. DELEGASI, Jurnal Ilmu Administrasi , 8 (1), 80.

Idris, I. 2006. Pengembangan Lembaga Keuangan Non Bank untuk Pemberdayaan UMKM. Jurnal Pengkajian Koperasi dan UMKM , I (2), 100.

Imelia. 1998. Peran Lembaga Keuangan Formal dan Informal dalam Aspek Permodalan Usaha Kecil di Kecamatan Lintao Buo I Sumatera Barat. Jurnal Manajemen dan Pembangunan, VII, 46.

Irfan, S.B. 2010. Peran Zakat Mengentaskan Kemiskinan dan Kesenjangan. Iqtishodia: Jurnal Ekonomi Islam Republika. Edisi Kamis, 29 Juli 2010, p.5.

Kartono, D. 2004. Pasar Modal Tradisional (Analisis Sosiologi Ekonomi terhadap Rentenir). Jurnal Sosiologi Dilema , 17 (1), 4.

Lapas Wanita Kelas II A. 2012. Data Kasus Tahanan Narapidana Wanita, Lapas Wanita Kelas II A. Kota Malang.

Lawang, R. 2007. Bank Kaum Miskin Kisah Yunus dan Grameen Bank Memerangi Kemiskinan. Jakarta: Buku Kita.

Lembaga Penelitian SMERU. 2004. Perencanaan dan Penganggaran Strategi Penanggulangan Kemiskinan di Daerah. Jakarta: Lembaga Penelitian SEMERU.

Mudiono. 2005. Dimensi-dimensi Masalah Sosial dan Pemberdayaan Masyarakat. Yogyakarta: APMD Press.

Nuhfil, H. 2012. Strategi Pencapaian Ketahanan Pangan Keluarga. Agricultural Economics Electronic Journal. Vol. 1, No. 1, p.1-7.

Oetomo, D. 2006. Metode Penelitian Sosial. Jakarta: Kencana.

Paguyuban Institute. 2009. Peran Lembaga Keuangan Mikro dalam Menanggulangi Kemiskinan Terkait dengan Kebijakan Otonomi Daerah, from http:/ / paguyubaninstitute.blogspot.com/2009/02/peran-lembaga-keuangan-mikro-dalam_06.html. Juli 2012.

Pemerintah Kota Malang. 2009. Potensi dan Perkembangan Kota Malang Tahun 2009. Malang: Pemerintah Kota Malang. 
Permana, E. A. 2010. "Bank Thithil" Sebagai Underground Economy, Latar Belakang Timbulnya dan Implikasi Sosial Ekonomi di Perkampungan (Studi Kasus di Kecamatan Sukun, Kotamadya Malang), Tesis, Jurusan Ilmu Ekonomi Pembangunan, Fakultas Ekonomi Universitas Brawijaya.

Rinjin, K. 2000. Pengantar Perbankan dan Lembaga Keuangan Bukan Bank. Jakarta: Gramedia Pustaka Tama.

Satria, D. 2009. Ekonomi, Uang dan Bank. Universitas Brawijaya Press: Malang.

Shalah, A.S. dan Abdullah, A.M. 2008. Ma La Yasa' at_Tajira Jahluhu. Abu, U.B. (penerjemah). Fikih Ekonomi Keuangan Islam. Darul Haq.

Simorangkir, O. P. 2004. Lembaga Keuangan Bank dan Non Bank. Jakarta: Ghalia Indonesia.

Sujadi. 2005. Profesionalisme Birokrasi Dalam Pelayanan Publik, Tesis, Program Magister Ilmu Administrasi, Program Pascasarjana Sekolah Tinggi Ilmu Administrasi Malang.

Supriatna, A. 2009. Pola Pelayanan Pembiayaan Sstem Kredit Mkro Usaha Tani di Tingkat Pedesaan. Jurnal Litbang Pertanian, 28 (3), 112.

Suradi. 2007. Pembangunan Manusia, Kemiskinan dan Kesejahteraan Sosial (Kajian tentang kebijakan pembangunan kesejahteraan sosial di nusa tenggara barat). Jurnal Penelitian dan Pengembangan Kesejahteraan Sosial. Vol 12, No. 03, p.1.

Susila, I. 2007. Analisis Efisiensi Lembaga Keuangan Mikro. Jurnal Ekonomi Pembangunan , 8 (2), 227.

Usman. 2009. Metodologi Penelitian Sosial. Jakarta: Bumi Aksara.

Venny, A. 2010. Memberantas Kemiskinan dari Parlemen. Jakarta: Kemitraan bagi Pembaruan Tata Pemerintahan di Indonesia.

Wibowo, P. dan Munawar, W. 2002. Studi Kredit Kecil Perkotaan di Kota Yogyakarta. SMERU. Wirdyaningsih. 2005. Bank dan Asuransi Islam di Indonesia. Prenada Media:Jakarta.

Yekti, A. dan Sulastyah, A. 2009. Eksistensi Lembaga Keuangan Mikro dalam Peningkatan Aksebilitas Pelaku Usaha Pertanian pada Sumber Permodalan di Pedesaan. Jurnal Ilmuilmu Pertanian , 114. 